\title{
Green synthesis of graphene and its cytotoxic effects in human breast cancer cells
}

\author{
This article was published in the following Dove Press journal: \\ International Journal of Nanomedicine \\ 9 March 2013 \\ Number of times this article has been viewed
}

\section{Sangiliyandi Gurunathan Jae Woong Han \\ Vasuki Eppakayala \\ Jin-Hoi Kim}

Department of Animal Biotechnology, Konkuk University, Seoul, South Korea
Correspondence: Sangiliyandi

Gurunathan; Jin-Hoi Kim

Department of Animal Biotechnology,

Konkuk University, I Hwayang-Dong,

Gwangin-gu, Seoul I43-70I, South Korea

$\mathrm{Tel}+8224503687$

Fax +82 24585414

Email gsangiliyandi@yahoo.com;

jhkim54I@konkuk.ac.kr
Background: This paper describes an environmentally friendly ("green") approach for the synthesis of soluble graphene using Bacillus marisflavi biomass as a reducing and stabilizing agent under mild conditions in aqueous solution. In addition, the study reported here investigated the cytotoxicity effects of graphene oxide (GO) and bacterially reduced graphene oxide (B-rGO) on the inhibition of cell viability, reactive oxygen species (ROS) generation, and membrane integrity in human breast cancer cells.

Methods: The reduction of GO was characterized by ultraviolet-visible spectroscopy. Size distribution was analyzed by dynamic light scattering. Further, X-ray diffraction and highresolution scanning electron microscopy were used to investigate the crystallinity of graphene and the morphologies of prepared graphene, respectively. The formation of defects further supports the bio-functionalization of graphene, as indicated in the Raman spectrum of B-rGO. Surface morphology and the thickness of the GO and B-rGO were analyzed using atomic force microscopy, while the biocompatibility of GO and B-rGO were investigated using WST-8 assays on MCF-7 cells. Finally, cellular toxicity was evaluated by ROS generation and membrane integrity assays.

Results: In this study, we demonstrated an environmentally friendly, cost-effective, and simple method for the preparation of water-soluble graphene using bacterial biomass. This reduction method avoids the use of toxic reagents such as hydrazine and hydrazine hydrate. The synthesized soluble graphene was confirmed using various analytical techniques. Our results suggest that both GO and B-rGO exhibit toxicity to MCF-7 cells in a dose-dependent manner, with a dose $>60 \mu \mathrm{g} / \mathrm{mL}$ exhibiting obvious cytotoxicity effects, such as decreasing cell viability, increasing ROS generation, and releasing of lactate dehydrogenase.

Conclusion: We developed a green and a simple approach to produce graphene using bacterial biomass as a reducing and stabilizing agent. The proposed approach confers B-rGO with great potential for various biological and biomedical applications.

Keywords: Bacillus marisflavi, graphene oxide, reduced graphene oxide, ultraviolet-visible spectroscopy, Raman spectroscopy

\section{Introduction}

Graphene, a carbon material with many potential applications due to its unique features, consists of a single-layer sp2-hybridized carbon atom network that is also compacted in a perfect honeycomb lattice. ${ }^{1}$ This unique chemical structure gives graphene excellent electrical, mechanical, and optical properties, thus attracting much commercial and academic research interest. ${ }^{2}$ As such, many synthetic strategies have been developed to make large quantities of high-quality graphene in a cost-effective manner. ${ }^{3}$ It was originally produced using micromechanical cleavage, ${ }^{4}$ but the large-scale production 
of graphene by this conventional method is rather difficult. Several approaches, including chemical vapor deposition, epitaxial growth, and chemical exfoliation have since been developed for the high-yield synthesis of high-quality graphene. ${ }^{5}$ The chemical methods have the advantage of large-scale production and are cost-effective, but are not compatible with large-scale synthesis in solution-processable form and require expensive high-temperature processes. ${ }^{5-7}$ Thus, chemical oxidation and reduction methods have been considered promising approaches for the synthesis of graphene from graphene oxide (GO). ${ }^{8}$

The chemical oxidation and reduction methods involve two steps: first, the exfoliation of graphite by oxidative treatment, then the reduction of the resulting GO using a suitable reducing agent. The reduction of GO is generally achieved using either reducing agents - such as hydrazine or one of its derivatives, sodium borohydride, hydroquinone, or a sulfur compound - or by hydrothermal and solvothermal protocols..$^{9,10}$ Most reducing agents are either toxic or explosive as well as difficult to handle for large-scale production. However, strong and toxic reduction agents and surfactants are essential to reduce GO fully in an aqueous phase. ${ }^{11}$ To solve this problem, many researchers have attempted to develop a new aqueous and environmentally friendly reduction strategy; these have included methods involving bacterial respiration, ${ }^{12}$ polyallylamine, ${ }^{13}$ potassium hydroxide, ${ }^{14}$ polyvinylpyrrolidone, ${ }^{15}$ ascorbic acid, ${ }^{16}$ sugar, ${ }^{17}$ baker's yeast, ${ }^{18}$ melatonin, ${ }^{19}$ and glucose.${ }^{20}$ Among the various nontoxic reduction agents, biomass has significant advantages because proteins can be used as reducing agents for the synthesis of graphene. Recently, Escherichia coli biomass was used as a reducing agent for GO. ${ }^{21}$

The toxicity of any fabricated nanomaterial is very important and because graphene-based nanomaterials are currently considered one of the most important nanomaterials for biomedical applications, several groups have recently investigated the toxicity and biocompatibility of graphene in relation to various cell types including bacteria. Akhavan and Ghaderi, ${ }^{22}$ for example, reported the interaction of the extremely sharp edges of graphene sheets with the cell wall membrane of bacteria, and the cytotoxicity of graphene in neural pheochromocytoma-derived PC12 cells through the generation of reactive oxygen species (ROS) by the graphene. ${ }^{23}$ Akhavan et $\mathrm{al}^{24}$ demonstrated a possible mechanism for the cytotoxicity of graphene sheets, in which the cells within the graphene sheets were aggregated. Liu et $\mathrm{al}^{25}$ proposed a membrane stress caused by direct contact with sharp nanosheets and also reported that graphene-based papers can inhibit the growth of bacteria but with minimal cytotoxicity. ${ }^{26}$ The cytotoxicity of graphene is also dose dependent. ${ }^{23,27}$ In a systematic study carried out by Chang et al, ${ }^{28}$ the authors determined that the loss of viability is dependent on size (Iarge-GO, medium-GO, and small-GO) and concentration of GO as well as the length of time cells are exposed to graphene materials. Zhang et $\mathrm{al}^{29}$ studied the distribution and biocompatibility of GO in mice and found that GO was predominantly deposited in the lungs, where it was retained for a long time. Compared with other carbon nanomaterials, GO exhibited a long blood circulation time and low uptake in the reticuloendothelial system. Recently, Akhavan et al ${ }^{30}$ demonstrated the sizedependent cyto and genotoxic effects of the Reduced graphene oxide nanoplatelets (rGONPs) on human mesenchymal stem cells.

Thus, as many of the currently available methods for producing graphene are not environmentally friendly, complicated, and require additional steps in the preparation process that restrict their applications in biological and biomedical fields, ${ }^{31}$ we developed a novel, cost-effective, simple, environmentally friendly approach to produce water-soluble graphene. Further, we examined the toxicity of the biologically reduced graphene oxide (B-rGO) in MCF-7 cells.

\section{Methods and materials Chemicals and bacteria}

Graphite powder was purchased from Sigma-Alrich (St Louis, MO, USA). Analytical-grade $\mathrm{NaOH}, \mathrm{KMnO}_{4}, N, N$ Dimethylacetamide, anhydrous ethanol, $98 \% \mathrm{H}_{2} \mathrm{SO}_{4}, 36 \%$ $\mathrm{HCl}$, and $30 \% \mathrm{H}_{2} \mathrm{O}_{2}$ aqueous solution were purchased from Sigma-Alrich and used directly without further purification. All aqueous solutions were prepared with deionized water. All other chemicals were also purchased from Sigma-Aldrich unless stated otherwise. Bacillus marisflavi GS3 (GenBank accession number, KC KC008578) was obtained from the GS Center for Life Sciences, Coimbatore, India.

\section{Preparation of biomass}

Media preparation and growth of bacteria were undertaken according to the methods described by Gurunathan et al. ${ }^{32}$ In brief, the pre-culture ( $10 \mathrm{~mL}$ of medium in a $50 \mathrm{~mL}$ flask) was inoculated with a single colony of $B$. marisflavi in nutrient broth medium and incubated on a rotary shaker at $37^{\circ} \mathrm{C}$ for 12 hours. The second pre-cultures were inoculated with the first pre-culture $(1 \% \mathrm{v} / \mathrm{v})$ and incubated on a rotary shaker at $37^{\circ} \mathrm{C}$ for 12 hours in $150 \mathrm{~mL}$ of batch medium in $500 \mathrm{~mL}$ 
shake flasks. Cells $(200 \mathrm{mg})$ were harvested by centrifugation and resuspended in $20 \mathrm{~mL}$ of water. The biomass obtained was thrice washed with phosphate buffer $(\mathrm{pH}$ 7.0) then collected and stored in a $50 \mathrm{~mL}$ tube until required for use in synthesis of reduced graphene.

\section{GO synthesis}

GO was prepared from graphite powder using a modified version of Hummers and Offeman's method. ${ }^{33,34}$ Graphite powder ( $2 \mathrm{~g}$ ) was mixed with $80 \mathrm{~mL} \mathrm{H}_{2} \mathrm{SO}_{4}$ and $20 \mathrm{~mL} \mathrm{HNO}_{3}$ in an ice bath. $\mathrm{KMnO}_{4}(12 \mathrm{~g})$ was slowly added to the mixture. The solution was heated at $35^{\circ} \mathrm{C}$ for 30 minutes, then diluted with $160 \mathrm{~mL}$ of $18 \mathrm{M} \Omega$ water. After 1 hour, the solution was further diluted by adding an additional $400 \mathrm{~mL}$ of $18 \mathrm{M} \Omega$ water, followed by the slow addition of $12 \mathrm{~mL}$ of $\mathrm{H}_{2} \mathrm{O}_{2}(30 \% \mathrm{v} / \mathrm{v})$. After these steps, the original black graphite suspension had been converted into a bright yellow graphite oxide solution. The precipitate of graphite oxide was isolated by centrifugation at $3000 \mathrm{rpm} /$ minutes for 15 minutes then washed with, and resuspended in, $18 \mathrm{M} \Omega$ water. The aqueous graphite oxide solution was then sonicated for 2 hours to facilitate the exfoliation of stacked graphite oxide sheets into monolayer or multi-layered GO sheets. The as-prepared GO yellow-brown solution $(\mathrm{mg} / \mathrm{mL})$ was used for further experiments.

\section{Synthesis of rGO}

Synthesis of rGO was carried out according to the method described previously. ${ }^{21}$ Briefly, bacteria were grown in a $500 \mathrm{~mL}$ Erlenmeyer flask containing lysogeny broth. The flasks were incubated for 21 hours in a shaker set at $120 \mathrm{rpm}$ and $37^{\circ} \mathrm{C}$. After the incubation period, the culture was centrifuged at 10,000 rpm and the resultant biomass used for the synthesis of rGO. In a typical reduction experiment, $200 \mathrm{mg}$ of B. marisflavi biomass was added to the GO dispersion $(0.5 \mathrm{mg} / \mathrm{mL})$ and the mixture stirred at $37^{\circ} \mathrm{C}$ for 72 hours. Following this, the stable black dispersion was centrifuged to remove excess bacteria as a supernatant liquid. The obtained black dispersion was designated "B-rGO" and used for further characterization.

\section{Characterization}

Ultraviolet-visible (UV-vis) spectra of the aqueous suspensions of GO and B-rGO were obtained using a WPA Biowave II UV/Visible Spectrophotometer (Biochrom, Cambridge, UK). X-ray diffraction (XRD) analyses were carried out on a D8 Discover X-ray diffractometer (Bruker, Karlsruhe, Germany). The high-resolution XRD patterns were measured at $3 \mathrm{Kw}$ with a copper target using a scintillation counter $\left(\lambda=1.5406^{\circ} \mathrm{A}\right)$ at $40 \mathrm{kV}$ and $40 \mathrm{~mA}$ were recorded in the range of $2 \theta=5^{\circ}-80^{\circ}$. A JSM- $6700 \mathrm{~F}$ semi-in-lens field emission scanning electron microscope (JEOL, Tokyo, Japan) operating at $10 \mathrm{kV}$ was used to acquire scanning electron microscopy (SEM) images. The solid samples were transferred to a carbon tape held into an SEM sample holder for analyses. Analyses of the samples were carried out at an average working distance of $6 \mathrm{~mm}$. Raman spectroscopy analyses were performed using a confocal micro-Raman LabRAM HR high-resolution Raman microscope (WITec, WITec Instruments Corp., TN, USA) in backscattering geometry with a charge-coupled device detector, and a $532 \mathrm{~nm}$ argon laser. The calibration was initially made using an internal silicon reference at $520 \mathrm{~cm}^{-1}$ and gave a peak position resolution of $<1 \mathrm{~cm}^{-1}$. The spectra were measured from 500 to $4500 \mathrm{~cm}^{-1}$. All samples were deposited on silicon wafers in powder form without using any solvent. Surface images were measured using tapping-mode atomic force microscopy (AFM) (SPA 400, Seiko Instruments, Chiba, Japan) operating at room temperature. Height and phase images were recorded simultaneously using nanoprobe cantilevers (SI-DF20, Seiko Instruments).

\section{Cell culture}

The MCF-7 human breast cancer cell line was kindly provided by Prof Ssang-Goo, Department of Animal Biotechnology, Konkuk University, Seoul, South Korea. Cells were cultured in Roswell Park Memorial Institute (RPMI) 1640 medium supplemented with $10 \%$ heat inactivated fetal calf serum, $10 \mathrm{mmol} / \mathrm{L}$ glutamine, and $50 \mu \mathrm{g} / \mathrm{mL}$ each of streptomycin and penicillin. Cells were grown to confluence at $37^{\circ} \mathrm{C}$ in a $5 \% \mathrm{CO}_{2}$ atmosphere. $\mathrm{GO}$ and $\mathrm{B}-\mathrm{rGO}$ suspensions were freshly prepared before exposure to cells, diluted to appropriate concentrations from 20 to $100 \mu \mathrm{g} / \mathrm{mL}$ with the culture medium, then immediately applied to the cells. Cells not treated with GO or B-rGO served as controls in each experiment.

\section{WST-cell viability assay}

WST-8 assay (water-soluble tetrazolium salt) was undertaken as described by Liao et al. ${ }^{27}$ Briefly, $1 \times 10^{4}$ cells were seeded in a 96-well plate and cultured in RPMI 1640 supplemented with $10 \%$ serum at $37^{\circ} \mathrm{C}$ under $5 \%$ $\mathrm{CO}_{2}$. After 24 hours, the cells were washed twice with $100 \mu \mathrm{L}$ of serum-free medium then incubated with $100 \mu \mathrm{L}$ of different concentrations of GO and B-rGO suspensions in serum-free minimal essential medium. 
After 24 hours' exposure, the cells were washed twice with serum-free medium and $15 \mu \mathrm{L}$ of Cell Counting Kit-8 solution was added to each well containing $100 \mu \mathrm{L}$ of serum-free minimal essential medium. After 1 hour of incubation at $37^{\circ} \mathrm{C}$ under $5 \% \mathrm{CO}_{2}, 80 \mu \mathrm{L}$ of the mixture was transferred to another 96-well plate, because residual GO and B-rGO can affect the absorbance values at $450 \mathrm{~nm}$. The absorbance of the mixture solutions was measured at $450 \mathrm{~nm}$, using a microplate reader.

Cell-free control experiments were performed to determine whether the synthesized GO and B-rGO would react directly with the WST- 8 reagents. Briefly, $100 \mu \mathrm{L}$ of GO and B-rGO suspensions with different concentrations $(20-100 \mu \mathrm{g} / \mathrm{mL})$ were added to a 96 -well plate and $10 \mu \mathrm{L}$ of WST-8 reagent solution was added to each well; the mixture solution was incubated at $37^{\circ} \mathrm{C}$ under $5 \% \mathrm{CO}_{2}$ for 1 hour. After incubation, the GO and $\mathrm{B}-\mathrm{rGO}$ were centrifuged and $50 \mu \mathrm{L}$ of the resulting supernatant was transferred to another 96-well plate. The optical density was measured at $450 \mathrm{~nm}$.

\section{Determination of ROS}

Intracellular ROS were measured based on the intracellular peroxide-dependent oxidation of $2^{\prime}, 7^{\prime}$-dichlorodihydrofluorescein diacetate (Invitrogen, Carlsbad, CA, USA) to form the fluorescent compound $2^{\prime}, 7^{\prime}$-dichlorofluorescein, as previously described. ${ }^{35}$ Cells were seeded onto 24-well plates at a density of $5 \times 10^{4}$ cells per well and cultured for 24 hours. After washing twice with phosphatebuffered saline (PBS), fresh medium containing different concentrations of GO or B-rGO was added and the cells incubated for another 24 hours. Following this, $20 \mu \mathrm{M}$ of $2^{\prime}, 7^{\prime}$-dichlorodihydrofluorescein diacetate was added to the cells and incubation continued for 30 minutes at $37^{\circ} \mathrm{C}$. Finally, the cells were rinsed with PBS, $2 \mathrm{~mL}$ of PBS was added to each well, and fluorescence intensity was determined with a Gemini $^{\text {TM }}$ EM microplate spectrofluorometer (Molecular Devices, Sunnyvale, CA, USA) with excitation at $485 \mathrm{~nm}$ and emission at $530 \mathrm{~nm}$.

\section{Membrane integrity}

The cell membrane integrity of MCF-7 cells was evaluated by determining the activity of lactate dehydrogenase (LDH) leaking out of the cells using an in vitro toxicology assay kit (TOX7, Sigma-Aldrich) according to the manufacturer's instructions. The LDH assay is based on the release of the cytosolic enzyme, LDH, from cells with damaged cellular membranes. Thus, in cell culture, the course of GO- and
B-rGO-induced cytotoxicity was followed quantitatively by measuring the activity of LDH in the supernatant. Briefly, cells were exposed to various concentrations of GO and B-rGO for 24 hours then $100 \mu \mathrm{L}$ per well of each cell-free supernatant was transferred in triplicate into wells in a 96-well plate, and $100 \mu \mathrm{L}$ of $\mathrm{LDH}$-assay reaction mixture was added to each well. After 3 hours' incubation under standard conditions, the optical density of the color generated was determined at a wavelength of $490 \mathrm{~nm}$ using a microplate reader.

\section{Cell mortality assay}

The cell mortality was evaluated using trypan blue assay as described by Chang et al. ${ }^{28}$ MCF-7 cells were plated in 6-well plates $\left(1 \times 10^{5}\right.$ cells per well $)$ and incubated for 24 hours. Then, GO or B-rGO was introduced to cells at different concentrations $(20,40,60,80$, and $100 \mu \mathrm{g} / \mathrm{mL})$ in culture medium. Cells cultured in the free medium were taken as the control. After 24 hours, the supernatant was collected and the cells detached with $300 \mu \mathrm{L}$ trypsinethylenediaminetetraacetic acid (EDTA) solution. The supernatant-detached cell mixture was centrifuged at $1200 \mathrm{rpm} /$ minutes for 5 minutes. The residue was then added to a $700 \mu \mathrm{L}$ trypan blue solution and dispersed. After 5 minutes staining, cells were counted using a cytometer. The dead cells were stained with blue color. Cell mortality (\%) was expressed as percentage of the dead cell number/ the total cell number.

\section{Results and discussion Characterization of GO and B-rGO by UV-vis spectroscopy}

Figure 1 shows the GO and $\mathrm{B}-\mathrm{rGO}$ that were produced using the modified method of Hummers and Offeman. ${ }^{33}$ To briefly reiterate, the graphite powder was first oxidized into graphite oxide using $\mathrm{KMnO}_{4} / \mathrm{H}_{2} \mathrm{SO}_{4}$, then the graphite oxide was exfoliated into GO sheets by ultra-sonication in water. In a typical reduction experiment, $200 \mathrm{mg}$ of bacterial biomass was added to the $\mathrm{GO}$ dispersion, and the mixture was stirred at $37^{\circ} \mathrm{C}$ for 72 hours. GO nanosheets were exfoliated from the graphite oxide, resulting in a clear, homogeneous, yellow-brown GO dispersion (pictured at left in Figure 1) and rGO nanosheets were obtained from the reduction of GO by bacterial biomass (pictured at right in Figure 1). This indicated that bacterial biomass played an important role in the reduction of GO to graphene. The obtained GO and B-rGO were highly soluble in water. They appeared different because of their distinct structural and physicochemical properties. ${ }^{36}$ The reduction of GO 


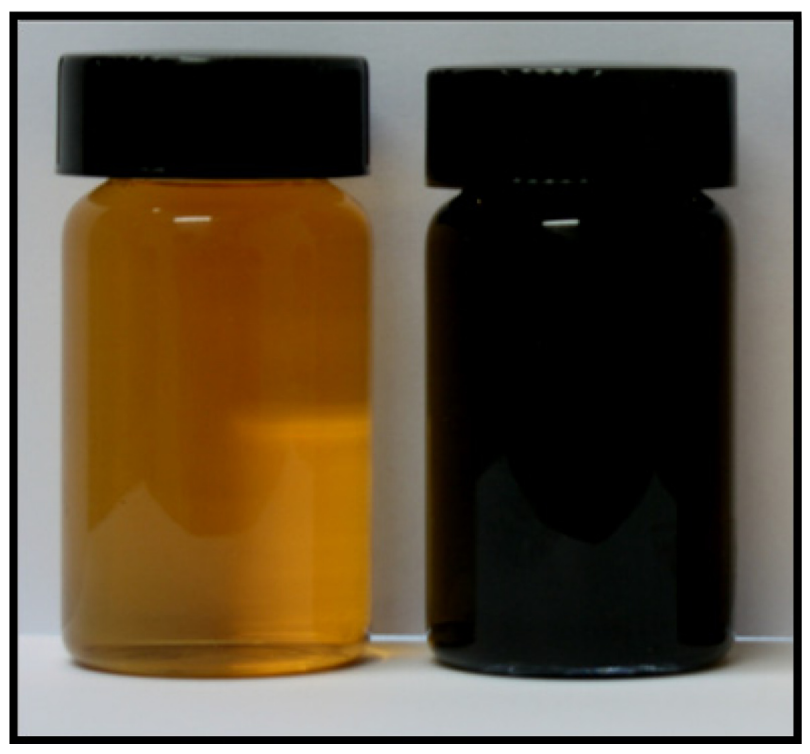

Figure I Photograph of graphene oxide (left) and bacterially reduced graphene oxide (right) at a concentration of $500 \mu \mathrm{g} / \mathrm{mL}$.

was also indicated by the color change of the solution before and after reaction (from yellow-brown to black), as shown in Figure 1. This can be attributed to the large amount of hydrophilic functional groups, such as carboxyl, hydroxyl, and epoxy groups, on the GO nanosheets. ${ }^{4}$ After the visibility check, we examined the water dispersibility of GO and B-rGO using UV-vis spectra analysis.

The optical absorption spectra of the GO and B-rGO suspensions are shown in Figure 2. After the reduction of GO by bacterial biomass, the color of the GO suspension changed from yellow-brown to black. The black color of the rGO suspensions indicates the restoration of the $\pi$ network between the sheets due to the removal of the oxygen-containing bonds resulting in electronic conjugation within the reduced sheets. ${ }^{37}$ The optical absorption spectra

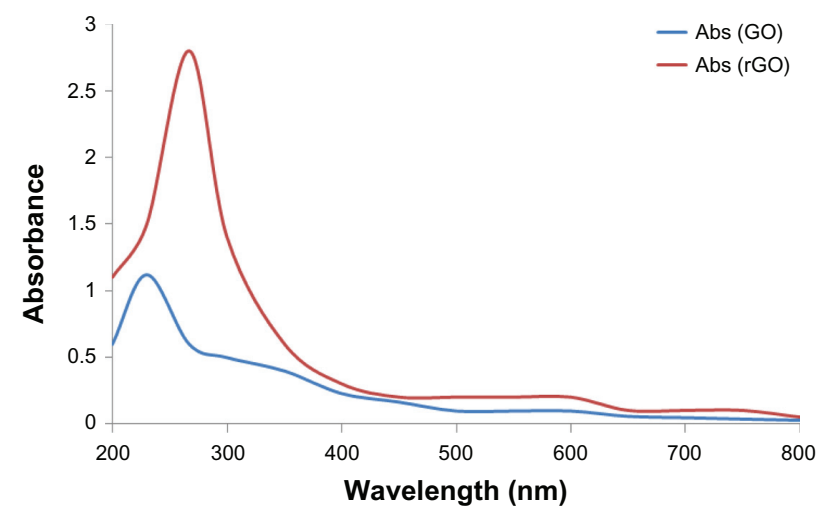

Figure 2 Ultraviolet-visible absorption spectra of graphene oxide (GO) and the reduced graphene oxide ( $\mathrm{rGO}$ ) suspension reduced by bacterial biomass $(50 \mu \mathrm{g} / \mathrm{mL})$. Abbreviation: Abs, absorption spectrum. also show that the absorption peaks of the GO suspension is around $230 \mathrm{~nm}$, while the absorption peak of the reduced suspensions shift into wavelengths of around $267 \mathrm{~nm}$, corresponding to deoxygenation of the GO suspension under the reduction processes. It shows that the GO might be reduced, the aromatic structure restored, and the reduction improved. Similar features and trends have been observed for the reduction of GO with L-ascorbic $\operatorname{acid}^{37}$ and L-cysteine, ${ }^{38}$ baker's yeast, ${ }^{18}$ and E. coli. ${ }^{21}$ Fernández-Merino et $\mathrm{al}^{37}$ suggested that the maximum red-shift value can be used as a standard to estimate the performance of the reducing agent.

\section{XRD analysis}

We further characterized the crystal structure of the rGO by XRD. Pristine graphite exhibits a basal reflection (002) peak at $2 \theta=25.6^{\circ}(\mathrm{d}$-spacing $=0.35 \mathrm{~nm}) .{ }^{25}$ Compared with pristine graphite, the diffraction peak of exfoliated GO appears at the lower angle $\left(2 \theta=11.7^{\circ}, d\right.$-spacing $\left.=0.76 \mathrm{~nm}\right)($ Figure $3 \mathrm{~A})$. The increase in d-spacing is due to the intercalation of water molecules and the formation of oxygen-containing functional groups between the layers of the graphite. ${ }^{3}$ As shown in Figure 3, the XRD pattern of B-rGO appeared as a broad band between $2 \theta=24^{\circ}$ and $2 \theta=29^{\circ}$ and crystalline peak centered at $2 \theta=25.5^{\circ}$ (Figure $3 \mathrm{~B}$ ) corresponding to the interlayer spacing of $0.35 \mathrm{~nm}$, which is significantly different from pristine graphite. The disappearance of the 002 reflection peak of GO and appearance of a broad band at $2 \theta=25.5^{\circ}$ with $\mathrm{B}-\mathrm{rGO}$ indicated the significant reduction of $\mathrm{GO}$ and formation of graphene of fewer layers. ${ }^{8,39-41}$

\section{Size analysis by dynamic light scattering (DLS)}

DLS measurement was performed in aqueous solution to elucidate the size of GO and rGO. It was found that the average size of GO layer was $1970 \mathrm{~nm}$ (Figure 4A). However, after the reduction of GO with biomass, an average size of $3833 \mathrm{~nm}$ was obtained under the same instrumental conditions (Figure 4B). This obvious change in size distribution indicated that the biomass not only acted as a reducing agent to prepare the rGO but was also functionalized on the surface of the resulting rGO, leading to an increased Brownian motion rate after the reduction process. Wang et $\mathrm{al}^{42}$ observed that after the reduction of GO with heparin, the average size of rGO layers was larger than that of GO. The rGO particles were formed by reducing GO nanosheets, which are about twice as large as GO nanosheets because of the aggregation of 

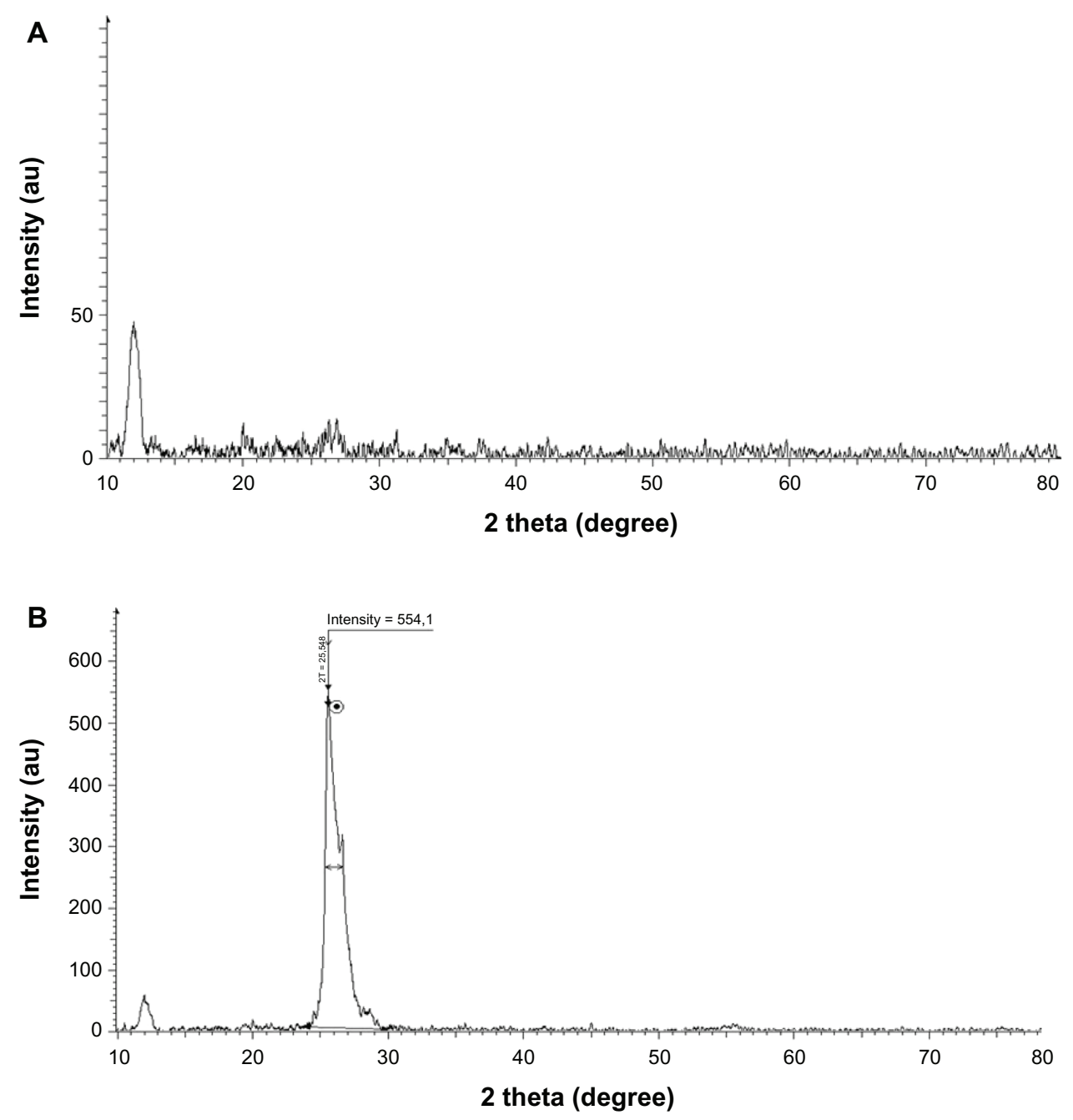

Figure 3 X-ray diffraction patterns of $(\mathbf{A})$ graphene oxide and $(\mathbf{B})$ bacterially reduced graphene oxide.

Note: The arrow indicates the position of crystalline peak of reduced graphene oxide. The dot represent the intensity value of peak.

B-rGO fragments. ${ }^{25}$ However, DLS results only show the size differences between GO and B-rGO layers. ${ }^{25}$ To confirm the actual sizes, the dispersions were dropped on aluminum foil and dozens of SEM images taken randomly for each sample (see the next section).

\section{SEM analysis}

As just mentioned, to examine the size of GO and B-rGO layers further, we used SEM analysis. The dispersions were dropped on aluminum foil and SEM images were taken randomly of each sample. Figure 5A shows SEM images of GO flakes and layers, revealing them to have a wavy, folded shape and to be in thin layers. The SEM images also revealed that the rGO material consists of individual sheets closely associated with each other (Figure 5A). Our results suggest that thin layers of nanosheets formed the GO dispersion, while the B-rGO dispersion was mainly comprised of larger, aggregated forms. Images of the rGO reveal that it consisted of several layers stacked on top of one another like silky sheets of paper (Figure 5B).

\section{Raman spectral analysis}

Raman spectroscopy analysis was carried out for both GO and B-rGO. Raman spectroscopy is highly sensitive to the electronic structure of a substance and has proven to be an essential tool for the characterization of carbon-based materials, especially $\mathrm{C}=\mathrm{C}$ double bonds, which lead to high Raman intensities. ${ }^{42}$ The common characteristics of carbon materials in Raman spectra are the $G$ line $\left(1580 \mathrm{~cm}^{-1}\right)$ related to the first-order scattering of the $E_{2 g}$ phonons of $\mathrm{sp}^{2}$ carbon atoms and the $\mathrm{D}$ line $\left(1350 \mathrm{~cm}^{-1}\right)$ as a breathing mode of $\kappa$-point phonons of $A_{1 \mathrm{~g}}$ symmetry which is assigned to structural imperfections induced by the attachment of hyrodxyl and/or epoxide groups on the carbon surface. ${ }^{19}$ Our results show that the G- and D-bands of GO appear at $1587 \mathrm{~cm}^{-1}$ and $1343 \mathrm{~cm}^{-1}$, respectively (Figure 6A). 
A

Size distribution by intensity

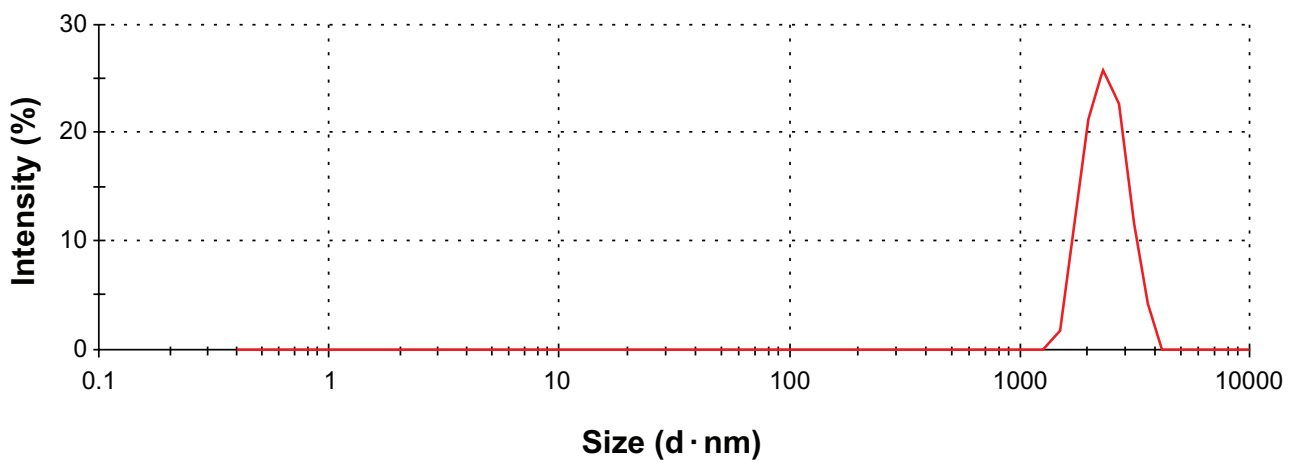

B

Size distribution by intensity

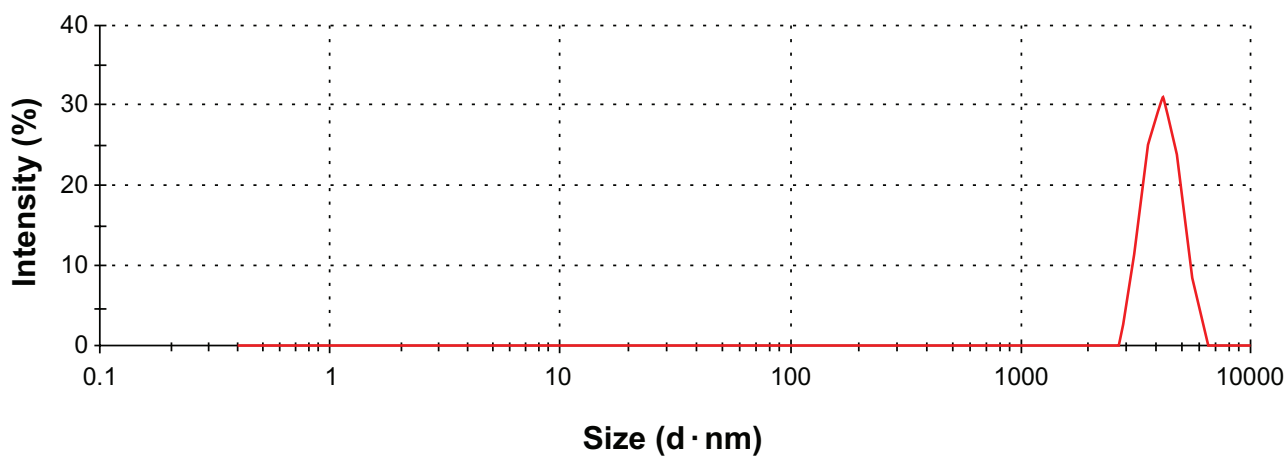

Figure 4 Hydrodynamic size distribution of $(\mathbf{A})$ graphene oxide and $(\mathbf{B})$ bacterially reduced graphene oxide $(500 \mu \mathrm{g} / \mathrm{mL}) \mathrm{measured}$ by dynamic light scattering at room temperature in deionized water.

Thus, the Raman spectrum of GO, as expected, displays a prominent G-peak (the $\mathrm{E}_{2 \mathrm{~g}}$ mode of $\mathrm{sp}^{2}$ carbon atoms) as the characteristic feature at $1587 \mathrm{~cm}^{-1}$. The Raman spectra further support the structural change before and after the reduction of GO by bacterial biomass. In the Raman spectrum of $\mathrm{GO}$ after reduction by bacterial biomass (ie, for the $\mathrm{B}-\mathrm{rGO}$ ), the G-band is broadened and shifted to around $1608 \mathrm{~cm}^{-1}$ and the D-band at $1395 \mathrm{~cm}^{-1}$ becomes prominent, indicating the reduction in size of the in-plane $\mathrm{sp}^{2}$ domains due to the extensive oxidation as a result of the bacterial biomass (Figure 6B). Interestingly, the Raman spectrum
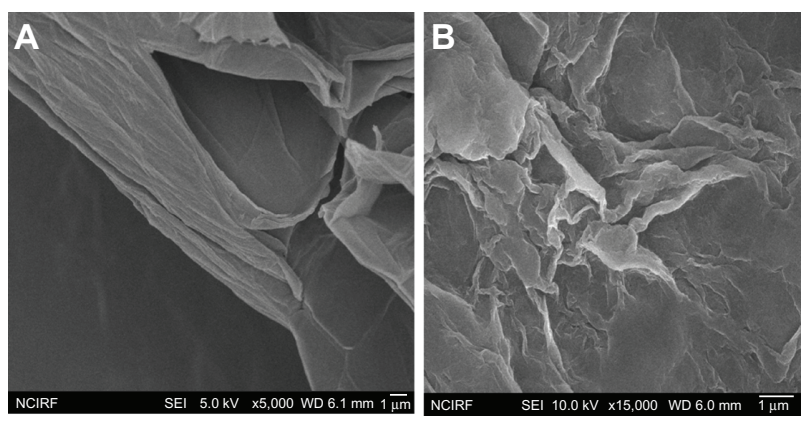

Figure 5 Scanning electron microscopy images of (A) graphene oxide and (B) bacterially reduced graphene oxide. of GO after reduction by bacterial biomass shows a higher D-/G-band intensity ratio than GO (1.4). In comparison to purified $\mathrm{GO}$, the $\mathrm{I}_{\mathrm{D}} / \mathrm{I}_{\mathrm{G}}$ ratio of the B-rGO is significantly increased (1.7), indicating the introduction of $\mathrm{sp}^{3}$ defects after functionalization and incomplete recovery of the structure of graphene. ${ }^{43}$ The variation in the relative intensities of the G- and D-bands in the Raman spectra of the GO during the reduction reveal the change of the electronic conjugation state. This change suggests that there was an increase in the number of $\mathrm{sp}^{2}$ domains with the reduction of GO.,44

Our Raman spectroscopy analysis results are in good agreement with two previous studies ${ }^{45,46}$ in which sulfur containing an amino acid (L-cysteine) was used to reduce GO into GO nanosheets and another study that developed a green and simple approach to the synthesis of graphene nanosheets using reducing sugars. ${ }^{16}$ In another study, reducing using wild carrot root caused the G-band of GO to broaden and shift to $1593 \mathrm{~cm}^{-1}$, while the D-band shifted to a lower region $\left(1346 \mathrm{~cm}^{-1}\right)$ and became more prominent, indicating the destruction of $\mathrm{sp}^{2}$ domains and the formation of defects in the sheets due to extensive oxidation..$^{33}$ When baker's yeast was used as a reducing agent, the D-band shift indicated successful functionalization of $\mathrm{rGO}^{18}$ Thus, our 

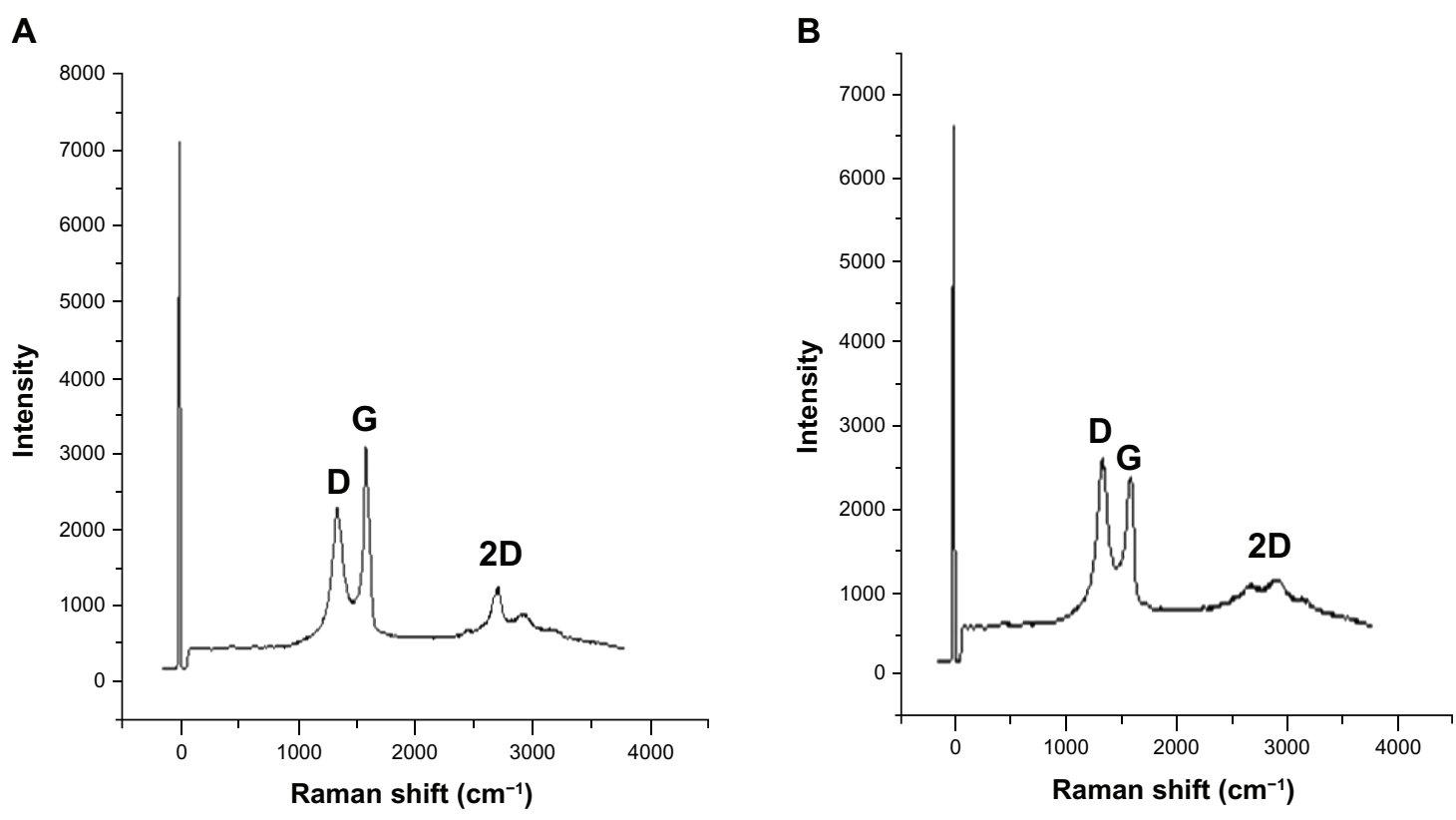

Figure 6 Raman spectra of (A) graphene oxide and (B) bacterially reduced graphene oxide.

observation is in good agreement with previous studies and supports the formation of functionalized graphene.

Further, to examine the quality of the synthesized graphene, we used Raman spectroscopy, which is a good choice for the nondestructive and quick inspection of a number of layers of graphene. ${ }^{47}$ Raman spectra of graphenebased materials have a $2 \mathrm{D}$ band that is sensitive to the stacking of graphene sheets. ${ }^{47}$ The characteristic shape and position of these $2 \mathrm{D}$ bands can be used to accurately differentiate single and bilayer graphene from multilayer graphene. ${ }^{47}$ In our experiment, we observed a significant feature and intensity of $2 \mathrm{D}$ bands located at $2600-3000 \mathrm{~cm}^{-1}$ in the Raman spectrum. As shown in Figure 6B, the 2D band of B-rGO is centered at about $2672 \mathrm{~cm}^{-1}$, with a low-intensity shoulder at higher wave numbers, while we analyzed the peak intensity ratio between $2 \mathrm{D}$ and G-bands to be 2.1. These results suggest that the synthesized graphene probably had a monolayer form.

\section{AFM analysis of GO and B-rGO}

AFM images were used to characterize the surface morphology and thickness of the GO and B-rGO nanosheets. As shown in Figure 7A, the representative AFM image and cross-section analysis of GO clearly exhibit flat sheets with some wrinkles and an average thickness of about $0.43 \mathrm{~nm}$, indicating the formation of single-layered GO nanosheets. Compared with GO, the B-rGO was thicker at $\sim 4.23 \mathrm{~nm}$, demonstrating that the biomass adhered and reduced the GO surface successfully (Figure 7B). Gao et al ${ }^{48}$ showed that L-tryptophan stabilized graphene sheets, which have an average thickness of $\sim 2.0 \mathrm{~nm}$. Khanra et a ${ }^{18}$ reported that the average thickness of yeast reduced graphene oxide (YR-GO) was $1.2 \mathrm{~nm}$, which is slightly greater than that of pure graphene. The greater thickness of YR-GO may be due to adsorption of nicotinamide adenine dinucleotide phosphate on the surface of graphene and/or the formation of bilayer functionalized graphene. Zhu et $\mathrm{al}^{17}$ observed that glucose-reduced graphene was thicker than exfoliated GO sheets due to the capping reagent used, which played an important role in increasing the thickness of the graphene. Similarly, Wang et al ${ }^{49}$ also reported that tea polyphenol produced graphene of increased thickness. Thus, the results of previous reports and the study presented here confirm that biomolecules play an important role in reduction and also in increasing the thickness of graphene. In turn, the increased thickness indicates that most of the oxygen-containing functional groups were removed after reduction.

\section{Effect of GO and B-rGO on the viability of MCF-7 cells}

The evaluation of the biocompatibility of graphene materials is an important factor in biological and biomedical applications, such as drug delivery and gene transfection. In our study, the cytotoxicity of GO and B-rGO was evaluated in MCF-7 cells. It has been found that 3-(4,5-Dimethylthiazol-2-yl)-2,5-diphenyltetrazolium bromide (MTT) assay is inappropriate for cytotoxicity tests of graphene materials, since the graphene reacts with the MTT 
A
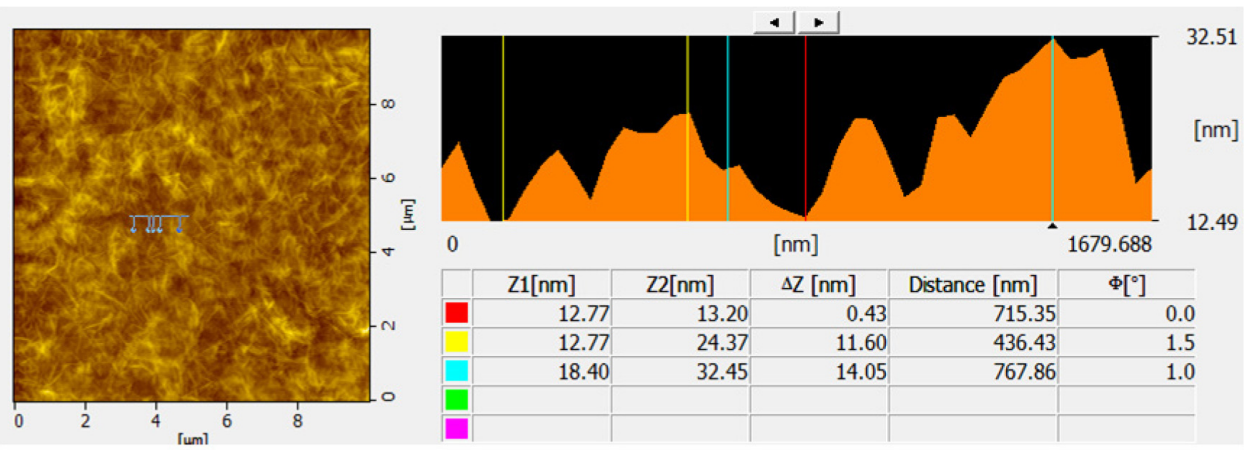

B
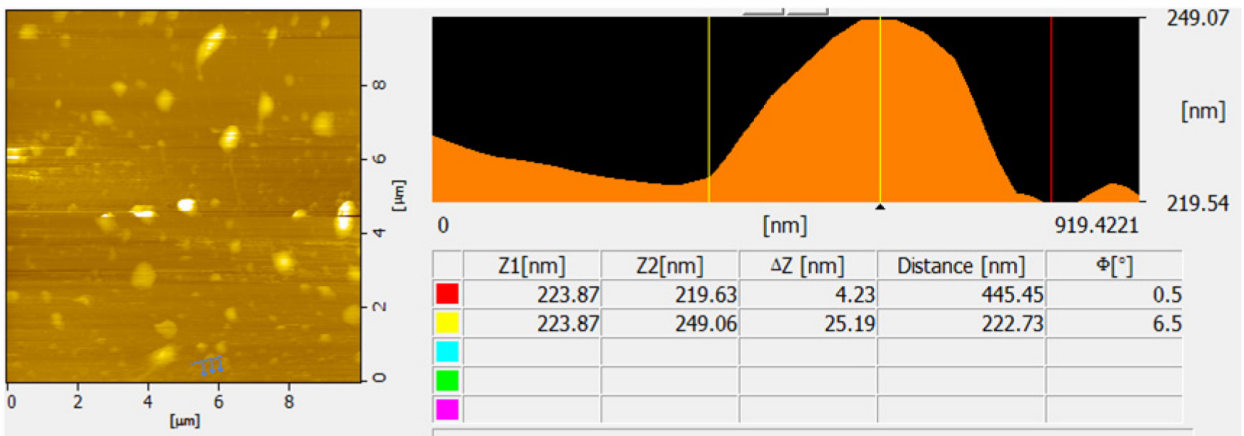

Figure 7 Atomic force microscopy images of $(\mathbf{A})$ graphene oxide and $(\mathbf{B})$ bacterially reduced graphene oxide.

reagent and forms purple formazan, leading to a false-positive result and overestimated cell viability. ${ }^{27}$ Thus, to obtain a precise toxic evaluation of $\mathrm{GO}$ and $\mathrm{B}-\mathrm{rGO}$, we employed the WST-8 assay, which does not react with GO or B-rGO, to measure the cytotoxicity of these two substances.

As already described in the "Methods and materials section," MCF-7 cells were incubated with GO and B-rGO for 24 hours, then the dose-dependent cytotoxicity was observed. As shown in Figure 8, both substances were significantly toxic, but there was an obvious decrease in cell viability with B-rGO of as much as $64.0 \% \pm 2.0 \%$ when the concentrations were in the range of $100 \mu \mathrm{g} / \mathrm{mL}$. Li et $\mathrm{al}^{50}$ demonstrated that pristine graphene can induce cytotoxicity by inducing depletion of the mitochondrial membrane potential, increasing generation of intracellular ROS, and subsequently triggering apoptosis by activating the mitochondrial pathway.

\section{ROS generation}

Nanoparticles can cause cell cytotoxicity by inducing the dysfunction of mitochondria ${ }^{51,52}$ and initiating the consequent accumulation of intracellular ROS. An increased level of ROS generation can be observed when cells are exposed to nanomaterials. Accumulation of intracellular ROS is the main characteristic of oxidative stress, so the detection of ROS generation reflects the intracellular oxidative stress status, which is an important indicator of cellular health. ${ }^{51}$ As we were interested to see the effect of GO and B-rGO on MCF-7 cells, we measured the intracellular ROS level in MCF-7 cells after incubation with GO and B-rGO for 24 hours. Figure 9 shows that $\mathrm{GO}$ and $\mathrm{B}-\mathrm{rGO}$ exposure induced intracellular ROS generation in a dose-dependent manner, with the highest ROS level found in MCF-7 cells exposed to a $100 \mu \mathrm{g} / \mathrm{mL}$ dose of B-rGO for 24 hours. The level of ROS production was significantly higher in B-rGO-treated cells than in GO-treated

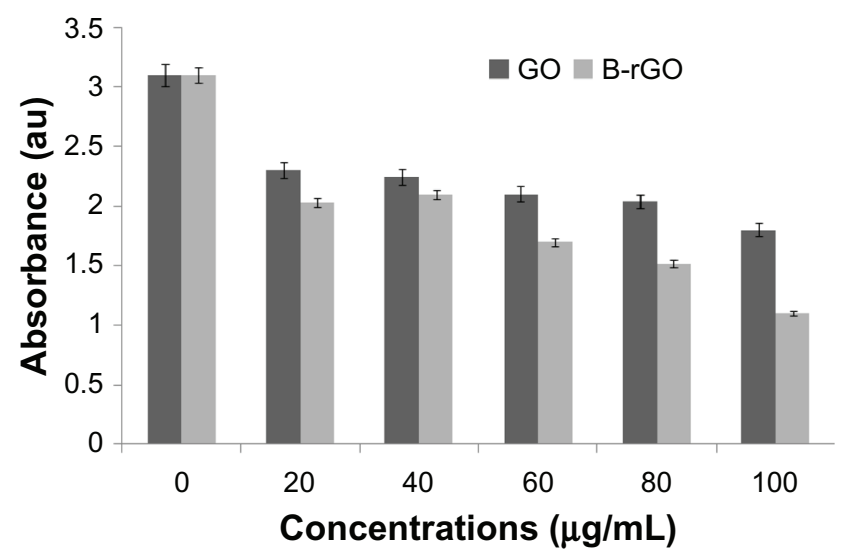

Figure 8 The effect of graphene oxide (GO) and bacterially reduced graphene oxide (B-rGO) on cell viability of MCF-7 cells.

Notes: The cell viability of MCF-7 cells was determined by WST-8 assay after 24 hours of exposure to different concentrations of GO or B-rGO. The results represent the means of three separate experiments and error bars represent the standard error of the mean. Treated groups showed statistically significant differences from the control group, as determined using Student's $t$-test $(P<0.05)$. 


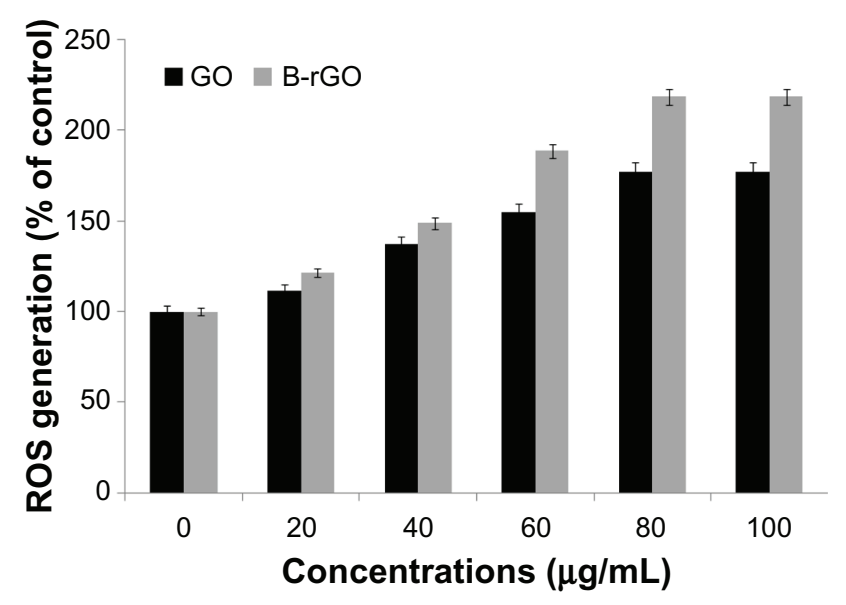

Figure 9 Generation of reactive oxygen species (ROS) in graphene oxide (GO)-and bacterially reduced graphene oxide (B-rGO)-treated MCF-7 cells.

Notes: The relative fluorescence of $2^{\prime}, 7^{\prime}$-dichlorofluorescein was measured using a spectrofluorometer with excitation at $485 \mathrm{~nm}$ and emission at $530 \mathrm{~nm}$. The results represent the means of three separate experiments and the error bars represent the standard error of the mean. Treated groups showed statistically significant differences from the control group, as determined by Student's $t$-test $(P<0.05)$.

cells. One reason for this could be the functionalization of GO by the biomass. Li et $\mathrm{al}^{50}$ showed that pristine graphene exposure induced intracellular ROS generation in a time- and dose-dependent manner. Chang et $\mathrm{al}^{28}$ explained that loss of viability was dependent on the size (large-GO, medium-GO, and small-GO) and concentration of the GO as well as the length of time the cells were exposed to graphene materials. The large surface areas of graphene-family nanosheets make surface reactions potentially important, including ROS production, antioxidant deactivation, ${ }^{53}$ and ROS quenching. ${ }^{54}$ However, the action of a graphene material is based on the number of layers it has, its lateral dimensions, and its surface chemistry as well as its surface area. Akhavan et $\mathrm{al}^{30}$ demonstrated the size- and concentration-dependent cytoand genotoxicity of GO sheets and nanoplatelets in human mesenchymal stem cells.

\section{Impact of GO and B-rGO on membrane integrity}

$\mathrm{LDH}$ is a soluble cytosolic enzyme that is released into the extracellular medium as a result of membrane damage; this consequently leads to apoptosis. It is widely accepted as an indicator of lytic cell death. Several studies have shown that nanomaterials can induce apoptosis or necrosis. ${ }^{51,55} \mathrm{LDH}$ release measures membrane damage, a hallmark of necrosis. To investigate the impact of GO and B-rGO on membrane integrity, the cells were treated with various concentrations of GO and B-rGO for 24 hours and then the extracellular LDH activity was measured. The results suggest that cell membrane integrity in MCF-7 cells was compromised by $\mathrm{GO}$ and
B-rGO at a concentration of $100 \mu \mathrm{g} / \mathrm{mL}$ in a dose-dependent manner (Figure 10). LDH activity was slightly increased in comparison to the control cells. The data obtained reveal that MCF-7 cells were sensitive to the GO and B-rGO treatment. In the LDH assay, increasing the concentration of the GO and B-rGO led to a higher absorbance reading, which indicates that the membrane integrity was compromised. Further, cellular contents were found in the media. Chang et $\mathrm{al}^{28}$ demonstrated that the LDH levels of GO-treated cells were slightly lower than those of their control cells.

\section{Cell mortality}

In general, while viability assays show the activity of cell mitochondria, the mortality analysis indicates cell death. ${ }^{28}$ In the study reported here, cell mortality was monitored by trypan blue exclusion assay, in which dead cells are stained in blue while the live ones remain unchanged. Mortality is expressed by the ratio of dead cells in total cells. The cells treated with GO and B-rGO showed significant cell death when compared with untreated cells (Figure 11).

Cheng et $\mathrm{al}^{31}$ observed that biopolymer functionalized rGO exhibits an ultralow hemolysis ratio and good compatibility in human umbilical vein endothelial cells, even at a high concentration of $100 \mu \mathrm{g} / \mathrm{mL}$. Heparinfunctionalized rGO has been shown to have good stability in aqueous solution, owing to the strong electrostatic and steric repulsions of the heparin, which adsorb on the surfaces of rGO sheets. ${ }^{42}$ Moreover, rGO has been shown to exhibit excellent biocompatibility and anticoagulant activity. ${ }^{42}$ $\mathrm{Hu}$ et $\mathrm{al}^{56}$ observed that human alveolar basal epithelial cells

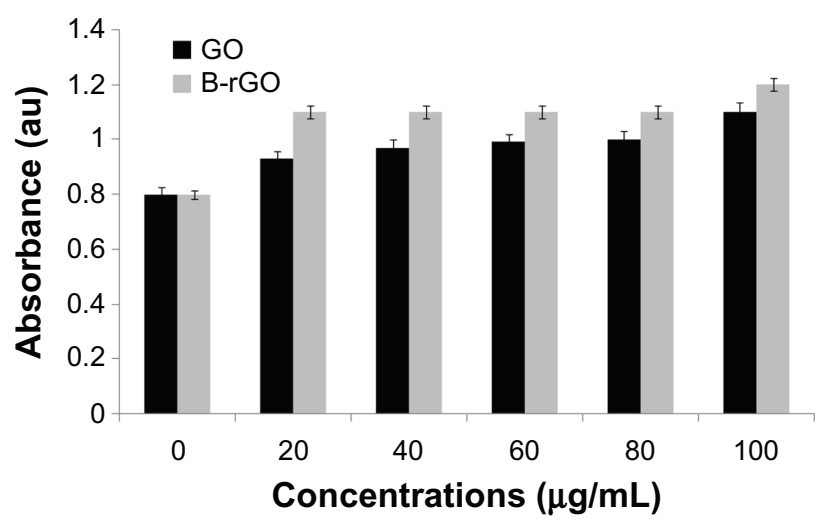

Figure 10 The effect of graphene oxide (GO) and bacterially reduced graphene oxide (B-rGO) on lactate dehydrogenase (LDH) activity in MCF-7 cells.

Notes: LDH activity was measured by changes in optical densities due to nicotinamide adenine dinucleotide reduction, monitored at $490 \mathrm{~nm}$, as described in "Materials and methods," using a cytotoxicity detection lactate dehydrogenase kit. The results represent the means of three separate experiments and the error bars represent the standard error of the mean. Treated groups showed statistically significant differences from the control group, as determined by Student's $t$-test $(P<0.05)$. 


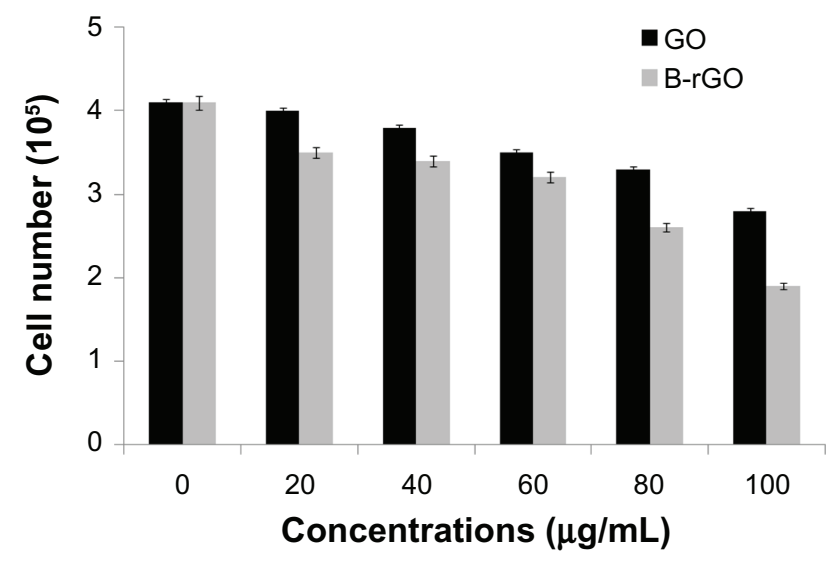

Figure II The effect of graphene oxide (GO) and bacterially reduced graphene oxide (B-rGO) on the mortality of MCF-7 cells.

Notes: The mortality of MCF-7 cells was determined using trypan blue assay after 24 hours of exposure to different concentrations of GO or B-rGO. The results represent the means of three separate experiments and the error bars represent the standard error of the mean. Treated groups showed statistically significant differences from the control group, as determined by Student's $t$-test $(P<0.05)$.

(A549) were sensitive to the presence of GO and showed concentration-dependent cytotoxicity. Further, graphene has been shown to induce cytotoxic effects and mitochondrial injury in human neuronal cells after 4 and 24 hours in a doseand shape-dependent manner. ${ }^{57}$ Ruiz et al ${ }^{58}$ studied the effect of GO film on the attachment and proliferation of mammalian colorectal adenocarcinoma HT-29 cells and suggested that the mammalian cells attached more efficiently to the GO films, without showing significant toxicity. Similarly, Li et $a 1^{59}$ reported the good biocompatibility of graphene films with mouse neuronal cells. Akhavan et $\mathrm{a}^{20}$ compared the efficiency of glucose- and hydrazine-reduced graphene for photothermal therapy for cancer cells. They found that the GO suspension reduced and functionalized by glucose in the presence of an iron catalyst had a biocompatible property, with an excellent near infrared photothermal therapy efficiency that was better than that of the hydrazine-rGO single- and multiwall carbon nanotube suspensions; these hydrazine-rGO suspensions showed some level of toxicity. Cheng et al ${ }^{31}$ demonstrated dose-dependent cytotoxicity in human umbilical vein endothelial cells with GO. They observed no toxicity in biopolymer functionalized rGO, but a higher level of cytotoxicity was seen when the cells were treated with hydrazine-reduced rGO.

Recently, our group also studied the effect of microbially reduced GO and hydrazine-reduced GO on mouse embryonic fibroblast cells. The results of that study suggest that microbially reduced GO has significant biocompatibility while hydrazine-reduced GO is highly toxic, indicating that the molecules used for the functionalization of GO and the type of cells influence biocompatibility. ${ }^{20}$

Although the mechanism responsible for graphene and GO toxicity has been reported on, no conclusions have been reached that are sufficient for risk assessment or regulation. ${ }^{60}$ Some studies have proposed that oxidative stress is one of the mechanisms involved in the cytotoxic effects of various nanomaterials such as carbon ones. ${ }^{23,28,61,62}$ Other studies have suggested that the cytotoxicity of graphene nanomaterials is due to the damaging of cell membranes through physical interaction with graphene's extremely sharp edges. ${ }^{22,26}$ Tazawa et $\mathrm{al}^{63}$ demonstrated that bacterial cells treated with GO and rGO lost membrane integrity. Liu et $\mathrm{l}^{25}$ proposed the mechanism of toxicity includes initial cell deposition on graphene-based materials and membrane stress caused by direct contact with sharp nanosheets. Our previous studies demonstrated that graphene nanomaterials interact with cells, eventually inducing toxicity. Both GO and B-rGO induce cytotoxic effects, and these effects are concentration dependent. Finally, toxicity also depends on the physicochemical properties of graphene-based materials, such as density of functional groups, size, conductivity, and the type of reducing agent used for deoxygenation of GO as well as on the cell types exposed to the materials.

\section{Conclusion}

This work demonstrates the synthesis of water-soluble graphene through reduction of GO using bacterial biomass. The reduction was carried out in aqueous medium at $37^{\circ} \mathrm{C}$ under mild conditions without toxic substances. The reduction of GO was confirmed by UV-vis spectroscopy, XRD, SEM, Raman spectroscopy and AFM. This technique has several advantages over traditional chemical reduction: it is costeffective, environmentally friendly, a simple approach, and an easy process for large-scale production. Our results indicate that $\mathrm{rGO}$ can be proposed as one of the promising nanomaterials for application in effective nanotherapy of cancer cells. Moreover, the as-prepared rGO might satisfy various biomedical applications. Thus, the proposed method provides a novel and promising approach for the study of the biological and biomedical applications of graphene.

\section{Acknowledgments}

This paper was supported by the SMART-Research Professor Program of Konkuk University. Dr Sangiliyandi Gurunathan was supported by the Konkuk University SMART-Full Time Professorship. This work was supported by the Woo Jang Choon Project (PJ007849) and the next generation 
of Biogreen 21 (PJ009107) from the Rural Development Administration, South Korea.

\section{Disclosure}

The authors report no conflicts of interest in this work.

\section{References}

1. Loh KP, Bao Q, G.Eda G, Chhowalla M. Graphene oxide as a chemically tunable platform for optical applications. Nat Chem. 2010;2(12): 1015-1024.

2. Geim KA, Novoselov KS. The rise of graphene. Nat Mater. 2007;6(3): 183-191.

3. Dreyer DR, Park S, Bielawski CW, Ruoff RS. The chemistry of graphene oxide. Chem Soc Rev. 2010;39(1):228-240.

4. Novoselov KS, Geim AK, Morozov SV, et al. Electric field effect in atomically thin carbon films. Science. 2004;306(5696):666-669.

5. Stankovich S, Dikin DA, Piner RD, et al. Synthesis of graphene-based nanosheets via chemical reduction of exfoliated graphite oxide. Carbon. 2007;45:1558-1565.

6. Berger C, Song Z, Li X, et al. Electronic confinement and coherence in patterned epitaxial graphene. Science. 2006;312(5777):1191-1196.

7. Kim KS, Zhao Y, Jang H, et al. Large-scale pattern growth of graphene films for stretchable transparent electrodes. Nature. 2009; 457(7230):706-710.

8. Li D, Müller MB, Gilje S, Kaner RB, Wallace GG. Processable aqueous dispersions of graphene nanosheets. Nat Nanotechnol. 2008; 3(2):101-105.

9. Tung VC, Allen MJ, Yang Y, Kaner RB. High-throughput solution processing of large-scale graphene. Nat Nanotechol. 2009;4(1):25-29.

10. Dubin S, Gilje S, Wang K, et al. A one-step, solvothermal reduction method for producing reduced graphene oxide dispersions in organic solvents. ACS Nano. 2010;4(7):3845-3852.

11. Zhou X, Liu Z. A scalable, solution-phase processing route to graphene oxide and graphene ultralarge sheets. Chem Commun (Camb). 2010; 46(15):2611-2613.

12. Salas EC, Sun Z, Lüttge A, Tour JM. Reduction of graphene oxide via bacterial respiration. ACS Nano. 2010;4(8):4852-4856.

13. Min K, Han TH, Kim J, Jung C, Hong SM, Koo CM. A facile route to fabricate stable reduced graphene oxide dispersions in various media and their transparent conductive thin films. J. Colloid Interface Sci. 2012;383(1):36-42.

14. Fan X, Peng W, Li Y, et al. Deoxygenation of exfoliated graphite oxide under alkaline conditions: a green route to graphene preparation. $A d v$ Mater. 2008;20(23):4490-4493.

15. Tang LA, Lee WC, Shi H, et al. Highly wrinkled cross-linked graphene oxide membranes for biological and charge-storage applications. Small. 2012;8(3):423-431.

16. Zhang J, Yang H, Shen G, Cheng P, Zhang J, Guo S. Reduction of graphene oxide via L-ascorbic acid. Chem Commun (Camb). 2010; 46(7):1112-1114.

17. Zhu C, Guo S, Fang Y, Dong S. Reducing sugar: new functional molecules for the green synthesis of graphene nanosheets. ACS Nano. 2010;4(4):2429-2437.

18. Khanra P, Kuila T, Kim NH, Bae SH, Yu DS, Lee JH. Simultaneous bio-functionalization and reduction of graphene oxide by baker's yeast. Chem Eng J. 2012;183:526-533.

19. Esfandiar A, Akhavan O, Irajizad A. Melatonin as a powerful bio-antioxidant for reduction of graphene oxide. J Mater Chem. 2011;21:10907-10914.

20. Akhavan O, Ghaderi E, Aghayee S, Fereydooni Y, Talebi A. The use of a glucose-reduced graphene oxide suspension for photothermal cancer therapy. J Mater Chem. 2012;22:13773-13781.

21. Gurunathan S, Han JW, Eppakayala V, Kim JH. Microbial reduction of graphene oxide by Escherichia coli: a green chemistry approach. Colloids Surf B Biointerfaces. 2013;102:772-777.
22. Akhavan O, Ghaderi E. Toxicity of graphene and graphene oxide nanowalls against bacteria. ACS Nano. 2010;4(10):5731-5736.

23. Zhang Y, Ali SF, Dervishi E, et al. Cytotoxicity effects of graphene and single-wall carbon nanotubes in neural phaeochromocytoma-derived PC12 cells. ACS Nano. 2010;4(6):3181-3186.

24. Akhavan O, Ghaderi E, Esfandiar A. Wrapping bacteria by graphene nanosheets for isolation from environment, reactivation by sonication, and inactivation by near-infrared irradiation. J Phys Chem B. 2011;115(19):6279-6288.

25. Liu S, Zeng TH, Hofmann M, et al. Antibacterial activity of graphite, graphite oxide, graphene oxide, and reduced graphene oxide: membrane and oxidative stress. ACS Nano. 2011;5(9):6971-6980.

26. $\mathrm{Hu} \mathrm{W}$, Peng $\mathrm{C}$, Luo W, et al. Graphene-based antibacterial paper. $A C S$ Nano. 2010;4(7):4317-4323.

27. Liao KH, Lin YS, Macosko CW, Haynes CL. Cytotoxicity of graphene oxide and graphene in human erythrocytes and skin fibroblasts. ACS Appl Mater Interfaces. 2011;3(7):2607-2615.

28. Chang Y, Yang ST, Liu JH, et al. In vitro toxicity evaluation of graphene oxide on A549 cells. Toxicol Lett. 2011;200(3):201-210.

29. Zhang X, Yin J, Peng C, et al. Distribution and biocompatibility studies of graphene oxide in mice after intravenous administration. Carbon. 2011;49(3):986-995.

30. Akhavan O, Ghaderi E, Akhavan A. Size-dependent genotoxicity of graphene nanoplatelets in human stem cells. Biomaterials. 2012;33(32): 8017-8025.

31. Cheng C, Nie S, Li S, et al. Biopolymer functionalized reduced graphene oxide with enhanced biocompatibility via mussel inspired coatings/ anchors. J Mater Chem B. 2013;1:265-275.

32. Gurunathan S, Kalishwaralal K, Vaidyanathan R, et al. Biosynthesis, purification and characterization of silver nanoparticles using Escherichia coli. Colloids Surf B Biointerfaces. 2009;74(1):328-335.

33. Hummers WS, Offeman RE. Preparation of graphitic oxide. JAm Chem Soc. 1958;80(6):1339-1339.

34. Wang G, Yang J, Park J, et al. Facile synthesis and characterization of graphene nanosheets. J Phys Chem C. 2008;112(22):8192-8195.

35. Shim HY, Park JH, Paik HD, Nah SY, Kim DS, Han YS. Acacetin-induced apoptosis of human breast cancer MCF-7 cells involves caspase cascade, mitochondria-mediated death signaling and SAPK/JNK1/2-c-Jun activation. Mol Cells. 2007;24(1):95-104.

36. Kuila T, Bose S, Khanra P, Mishra AK, Kim NH, Lee JH. Recent advances in graphene-based biosensors. Biosens Bioelectron. 2011; 26(12):4637-4648.

37. Fernández-Merino MJ, Guardia L, Paredes JL, et al. Vitamin C as an innocuous and safe reductant for the preparation of graphene suspensions from graphite oxide. J Phys Chem C. 2010;114:6426-6432.

38. Chen D, Li L, Guo L. An environment-friendly preparation of reduced graphene oxide nanosheets via amino acid. Nanotechnology. 2011;22(32):325601.

39. Moon IK, Lee J, Ruoff RS, Lee H. Reduced graphene oxide by chemical graphitization. Nat Commun. 2010;1:73.

40. Yang X, Zhang X, Ma Y, Huang Y, Wang Y, Chen Y. Superparamagnetic graphene oxide-Fe3O4 nanoparticles hybrid for controlled targeted drug carriers. J Mater Chem. 2009;19:2710-2714.

41. Hassan HM, Abdelsayed V, Khder AE, et al. Microwave synthesis of graphene sheets supporting metal nanocrystals in aqueous and organic media. J Mater Chem. 2009;19:3832-3837.

42. Wang Y, Zhang P, Liu CF, Zhan L, Li YF, Huang CZ. Green and easy synthesis of biocompatible graphene for use as an anticoagulant. RSC Adv. 2012;2:2322-2328.

43. McAllister MJ, Li JL, Adamson DH, et al. Single sheet functionalized graphene by oxidation and thermal expansion of graphite. Chem Mater. 2007;19(18):4396-4404.

44. Niyogi S, Bekyarova E, Itkis ME, et al. Spectroscopy of covalently functionalized graphene. Nano Lett. 2010;10(10):4061-4066.

45. Kudin KN, Ozbas B, Schniepp HC, Prud'homme RK, Aksay IA, Ca R. Raman spectra of graphite oxide and functionalized graphene sheets. Nano Lett. 2008;8(1):36-41. 
46. Eda G, Chhowalla M. Chemically derived graphene oxide: towards large-area thin-film electronics and optoelectronics. Adv Mater. 2010; 22(22):2392-2415.

47. Ferrari AC, Meyer JC, Scardaci V, et al. Raman spectrum of graphene and graphene layers. Phy Rev Lett. 2006;97(18):187401.

48. Gao J, Liu F, Liu Y, Ma N, Wang Z, Zhang X. Environment-friendly method to produce graphene that employs vitamin $\mathrm{C}$ and amino acid. Chem Mater. 2010;22(7):2213-2218.

49. Wang Y, Shi Z, Yin J. Facile synthesis of soluble graphene via a green reduction of graphene oxide in tea solution and its biocomposites. ACS Appl Mater Interfaces. 2011;3(4):1127-1133.

50. Li Y, Liu Y, Fu Y, et al. The triggering of apoptosis in macrophages by pristine graphene through the MAPK and TGF-beta signaling pathways. Biomaterials. 2012;33(2):402-411.

51. Nel A, Xia T, Mädler L, Li N. Toxic potential of materials at the nanolevel. Science. 2006;311(5761):622-627.

52. Wang Y, Tan S, Wang J, et al. Direct imaging of apoptosis process of neural stem cells exposed to porous silica nanoparticles. Curr Nanosci. 2010;6(3):292-297.

53. Liu X, Gurel V, Morris D, et al. Bioavailability of nickel in single-wall carbon nanotubes. Adv Mater. 2007;19(19):2790-2796.

54. Fenoglio I, Tomatis M, Lison D, et al. Reactivity of carbon nanotubes: free radical generation or scavenging activity? Free Radical Biol Med. 2006;40(7):1227-1233.

55. Shi L, Hernandez B, Selke M. Singlet oxygen generation from water-soluble quantum dot-organic dye nanocomposites. $\mathrm{J} \mathrm{Am} \mathrm{Chem}$ Soc. 2006;128(19):6278-6279.
56. Hu W, Peng C, Lv M, et al. Protein corona-mediated mitigation of cytotoxicity of graphene oxide. ACS Nano. 2011;5(5):3693-3700.

57. Zhang L, Xia J, Zhao Q, Liu L, Zhang Z. Functional graphene oxide as a nanocarrier for controlled loading and targeted delivery of mixed anticancer drugs. Small. 2010;6(4):537-544.

58. Ruiz ON, Fernando KA, Wang B, et al. Graphene oxide: a nonspecific enhancer of cellular growth. ACS Nano. 2011;5(10):8100-8107.

59. Li Y, Zhang P, Du Q, et al. Adsorption of fluoride from aqueous solution by graphene. J Colloid Interface Sci. 2011;363(1):348-354.

60. Gurunathan S, Han JW, Eppakayala V, Kim JH. Biocompatibility of microbially reduced graphene oxide in primary mouse embryonic fibroblast cells. Colloids Surf B Biointerfaces. 2013;105:58-66.

61. Sanchez VC, Jachak A, Hurt RH, Kane AB. Biological interactions of graphene-family nanomaterials: an interdisciplinary review. Chem Res Toxicol. 2011;25(1):15-34.

62. Gurunathan S, Han JW, Dayem AA, Eppakayala V, Kim JH. Oxidative stress-mediated antibacterial activity of graphene oxide and reduced graphene oxide in Pseudomonas aeruginosa. Int $J$ Nanomedicine. 2012;7:5901-5914.

63. Tazawa H, Tatemichi M, Sawa T, et al. Oxidative and nitrative stress caused by subcutaneous implantation of a foreign body accelerates sarcoma development in Trp53+/- mice. Carcinogenesis. 2007;28(1): 191-198.
International Journal of Nanomedicine

\section{Publish your work in this journal}

The International Journal of Nanomedicine is an international, peerreviewed journal focusing on the application of nanotechnology in diagnostics, therapeutics, and drug delivery systems throughout the biomedical field. This journal is indexed on PubMed Central,

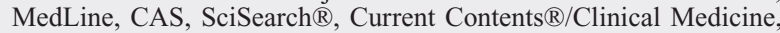

\section{Dovepress}

Journal Citation Reports/Science Edition, EMBase, Scopus and the Elsevier Bibliographic databases. The manuscript management system is completely online and includes a very quick and fair peer-review system, which is all easy to use. Visit http://www.dovepress.com/ testimonials.php to read real quotes from published authors. 